Бойко Р. В. к.т.н., с.н.с

Семененко О. М. д.військ.н, с.н.с ${ }^{2}$

Водчиць О. Г. к.т.н., доцент ${ }^{3}$

Добровольський Ю. Б. к.т.н., доцент ${ }^{3}$

Абрамов А. П. ${ }^{2}$
(ORCID: 0000-0001-7240-4299);

(ORCID: 0000-0001-6477-3414);

(ORCID: 0000-0002-3294-7632);

(ORCID: 0000-0002-1077-1402);

(ORCID: 0000-0001-8514-6217)

1 - Центр воєнно-стратегічних досліджень Національного університету оборони України імені Івана Черняховського, Київ;

2 - Центральний науково-дослідний інститут Збройних Сил України, Київ;

3 - Військова кафедра Національного авіаційного університету, Київ

\title{
Аналіз стану забезпечення Збройних Сил України фінансовими ресурсами та порядок комплексного планування їх розвитку
}

Резюме. У статті проведено аналіз стану фінансового забезпечення Збройних Сил України фінансовими ресурсами у 2005 - 2018 роках і здійснено прогноз цього стану на довгострокову перспективу методом екстраполяції, також визначений порядок комплексного планування розвитку ЗС України за основними етапами його реалізації в системі оборонного планування.

Ключові слова: економічне забезпечення; комплексне планування розвитку Збройних Сил України; стратегічне планування; ресурсне забезпечення; потреби збройних сил; воєнно-економічні вимоги.

Постановка проблеми. Розвиток збройних сил (3С) будь-якої держави визначається соціально-політичним устроєм країни, їі політикою, економікою та її воєнною доктриною. Воєнна доктрина будь-якої держави підпорядковуються двом взаємопов'язаним принципам - політичним i воєнно-технічним, які, зі свого боку, визначаються політикою держави. Перший принцип торкається питань формування політичних цілей і завдань держави у війні, а другий - питань будівництва та розвитку власних 3С, їх використання у війні для досягнення політичних цілей. Політичні цілі та стратегічні завдання держави формуються на основі іii реальних воєнно-економічних можливостей. Адекватність воєнної доктрини полягає в іiі суворій відповідності загальним цілям розвитку держави й тим матеріальним $і$ людським ресурсам, які $є$ у розпорядженні держави в період дії доктрини. Вірне розуміння спеціалістами оборонного планування основних принципів воєнної доктрини можливо тільки за умов постійного аналізу можливостей держави щодо економічного розвитку 3С України та послідовності (порядку) комплексного планування їх розвитку на середньо- та довгострокову перспективу.

Аналіз останніх досліджень i публікацій свідчить, що в сучасних умовах розвитку держави питанням воєнної безпеки приділяється значна увага з боку керівництва держави [1-4]. Водночас, економічні можливості держави обмежені, тому завдання воєнно-економічного обгрунтування та раціонального вибору шляхів розвитку 3С України на сьогодні $є$ пріоритетними під час планування подальшого розвитку 3С України.

Економіка держави $є$ матеріальною базою воєнного будівництва. Вона забезпечує 3С людськими та матеріальними ресурсами. До основних напрямів економічного забезпечення будівництва 3С України можна віднести: задоволення потреб ЗС України в озброєнні та військовій техніці (ОВТ) та інших матеріальних засобах; комплектування кадрами; удосконалення науково-технічної, матеріальної бази та методів планування економічного забезпечення будівництва 3С України. Важливими умовами забезпечення відповідності між політичними та воєннотехнічними сторонами воєнної доктрини є: проведення необхідних досліджень щодо обгрунтування цілей та завдань ЗС України; визначення перспективного обрису ЗС України (складу 3С у мирний та воєнний час необхідного для виконання поставлених завдань); вибір основних напрямів розвитку 3С України на середньо- та довгострокову перспективу. Досягання відповідності між політичними цілями та економічними можливостями держави є об'єктивною необхідністю. Економічні можливості України в період 2005-2013 рр., давали змогу розвивати ЗС України, але акцент витрачання 
державних коштів був зміщений у бік постійного їх скорочування та реформування, витрачаючи на це значні обсяги фінансових ресурсів (рис. 1, табл. 1) [4].

Будівництво ЗС України має завжди орієнтуватися на визначені політичні цілі та обсяг ресурсів, які виділяються на потреби оборони, як у мирний, так і у воєнний час, відповідати потребам щодо захисту держави. В умовах обмежених можливостей держави щодо забезпечення оборонних потреб у мирний час, виникає задача вибору та обгрунтування 3 усієї сукупності можливих політичних цілей тих, які реальніше досягти, та визначається пріоритетність їх досягнення.
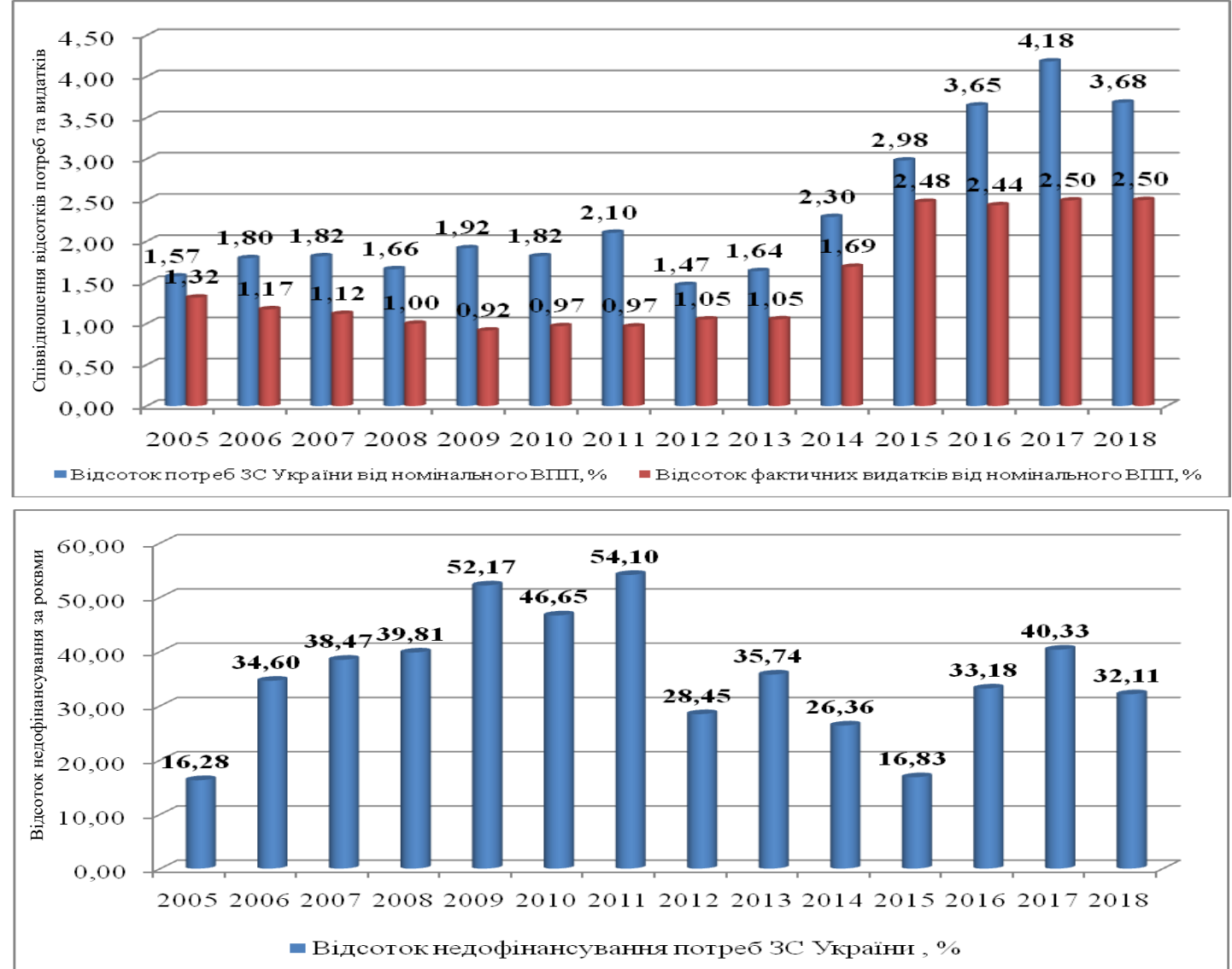

Рис. 1 - Показники потреб і недофінансування потреб ЗС України в період 2005 - 2018 рр.

Таблиця 1

Результати фінансування потреб ЗС України в період 2005 - 2018 рр.

\begin{tabular}{|l|c|c|c|c|c|c|c|c|}
\hline Рік & $\begin{array}{c}\text { Номінальний } \\
\text { ВВП, } \\
\text { млрд грн }\end{array}$ & $\begin{array}{c}\text { Номінальний } \\
\text { ВВП, } \\
\text { млдд дол. } \\
\text { США }\end{array}$ & $\begin{array}{c}\text { Потреби } \\
\text { 3С } \\
\text { України, } \\
\text { млрд грн }\end{array}$ & $\begin{array}{c}\text { Фактичні } \\
\text { видатки } \\
\text { 3С } \\
\text { України, } \\
\text { млрд грн }\end{array}$ & $\begin{array}{c}\text { Відсоток } \\
\text { потреб 3С } \\
\text { України від } \\
\text { номінального } \\
\text { ВПП, \% }\end{array}$ & $\begin{array}{c}\text { Відсоток } \\
\text { фактичних } \\
\text { видатків від } \\
\text { номінального } \\
\text { ВПП, \% }\end{array}$ & $\begin{array}{c}\text { Відсоток } \\
\text { недофінансу } \\
\text { вання } \\
\text { потреб 3С } \\
\text { України, \% }\end{array}$ & $\begin{array}{c}\text { Обсяги } \\
\text { недофінансу- } \\
\text { вання потреб, } \\
\text { млрд грн }\end{array}$ \\
\hline $\mathbf{2 0 0 5}$ & 441,45 & 86,14 & 6,94 & 5,81 & 1,57 & 1,32 & 16,28 & 1,13 \\
\hline $\mathbf{2 0 0 6}$ & 544,15 & 107,75 & 9,77 & 6,39 & 1,80 & 1,17 & 34,60 & 3,38 \\
\hline $\mathbf{2 0 0 7}$ & 720,73 & 142,72 & 13,10 & 8,06 & 1,82 & 1,12 & 38,47 & 5,04 \\
\hline $\mathbf{2 0 0 8}$ & 948,06 & 179,99 & 15,75 & 9,48 & 1,66 & 1,00 & 39,81 & 6,27 \\
\hline $\mathbf{2 0 0 9}$ & 913,35 & 117,23 & 17,50 & 8,37 & 1,92 & 0,92 & 52,17 & 9,13 \\
\hline $\mathbf{2 0 1 0}$ & 1082,57 & 136,42 & 19,68 & 10,50 & 1,82 & 0,97 & 46,65 & 9,18 \\
\hline $\mathbf{2 0 1 1}$ & 1316,60 & 163,16 & 27,69 & 12,71 & 2,10 & 0,97 & 54,10 & 14,98 \\
\hline $\mathbf{2 0 1 3}$ & 1408,89 & 175,78 & 20,70 & 14,81 & 1,47 & 1,05 & 28,45 & 5,89 \\
\hline $\mathbf{2 0 1 4}$ & 1454,93 & 183,31 & 23,84 & 15,32 & 1,64 & 1,05 & 35,74 & 8,52 \\
\hline $\mathbf{2 0 1 5}$ & 1566,73 & 131,81 & 35,96 & 26,48 & 2,30 & 1,69 & 26,36 & 9,48 \\
\hline $\mathbf{2 0 1 6}$ & 2383,46 & 90,62 & 59,01 & 49,08 & 2,98 & 2,48 & 16,83 & 9,93 \\
\hline $\mathbf{2 0 1 7}$ & 2584,90 & 93,27 & 86,95 & 58,10 & 3,65 & 2,44 & 33,18 & 28,85 \\
\hline $\mathbf{2 0 1 8}$ & 3332,30 & 111,08 & 122,75 & 83,33 & 3,68 & 2,50 & 32,11 & 39,42 \\
\hline
\end{tabular}

Під час обгрунтування політичних цілей важливо враховувати економічні та соціально-політичні умови, стан і можливості власних та інших ЗС. Це потребує проведення спеціальних воєнно-економічних досліджень, під час яких потрібно аналізувати питання узгодження політичних цілей $\mathrm{i}$ напрямів будівництва 3С України. Під час такого узгодження змінними можуть бути не тільки визначені цілі, а й ресурси, які необхідні для 
задоволення потреб оборони. Унаслідок такого узгодження має бути вироблена концепція будівництва ЗС України, в якій політичні цілі й стратегічні завдання збалансовані із силами для їх виконання та необхідними ресурсами. Обгрунтовані таким чином політичні цілі та відповідний їм обсяг ресурсів є базою для подальшої роботи щодо обгрунтування перспектив розвитку ЗС України на середньо- та довгострокову перспективу.

Метою статті $\epsilon$ аналіз стану фінансового забезпечення Збройних Сил України фінансовими ресурсам, здійснення прогнозу цього стану на довгострокову перспективу методом екстраполяції та визначення порядку комплексного планування розвитку 3С України за основними етапами його реалізації в системі оборонного планування.

Виклад основного матеріалу. Розвиток OBT, необхідність розроблення та виробництва або закупівлі досконаліших зразків ОВТ для підтримання ЗС на відповідному рівні технічного оснащення постійно підвищують вимоги до планування розвитку 3С, що потребує постійного зростання ресурсного забезпечення ЗС. Для ефективного використання ресурсів, які виділяються на оборону, ключовим завданням $\epsilon$ удосконалення методології воєнноекономічного обгрунтування програм розвитку ЗС України як на етапі їх формування, так і під час їх безпосереднього виконання.

Аналіз системи оборонного планування в Україні показав, що здійснення воєнноекономічних досліджень щодо обгрунтування доцільних варіантів (напрямів) розвитку 3С України, дасть змогу отримати об'єктивну порівняльну оцінку альтернативних шляхів досягнення політичних цілей та створить наукову основу для вибору стратегії будівництва 3С України. Удосконалення системи оборонного планування в ЗС України має відбуватися за декількома напрямами. До основних можна віднести: постійне удосконалення методології комплексного планування розвитку $3 \mathrm{C}$; всебічний розвиток системи обгрунтування стратегічних завдань ЗС в цілому та кожного виду ЗС окремо; розроблення й постійне удосконалення методології воєнно-економічного обгрунтування програм розвитку ЗС України; забезпечення тісного зв'язку між задачами 3С i розвитком ОВТ; підготовка та проведення заходів організаційного характеру щодо постійного забезпечення ефективного виконання програм i планів розвитку 3С України. Необхідність та актуальність питань подальшого удосконалення методології комплексного планування розвитку ЗС України та методології воєнно-економічного обгрунтування програм розвитку ЗС України обумовлена змінами у воєнно-політичній обстановці як у середині країни, так і поза іiі межами. Удосконалення системи оборонного планування ЗС України має велике значення для забезпечення системного розвитку кожного структурного елементу 3С, раціонального розподілу ресурсів між ними, знаходження оптимальної сукупності заходів щодо розвитку центральних органів управління з підготовки кадрів, тилового та технічного забезпечення тощо. Сучасні умови виконання завдань ЗС України показують, що до виконання більшості завдань можуть використовуватися сили і засоби декількох видів ЗС одночасно. За таких умов підвищується значення надвидового (у масштабі 3С) перспективного планування та роль ГШ ЗС України щодо вироблення доцільніших і раціональніших рішень із питань розвитку та застосування видів 3С, а також забезпечення ресурсами.

Якісне наукове обгрунтування планування 3С України можливо тільки за наявності достатньої інформації: про умови розвитку ЗС України; стан (ефективність) виконання програм (планів) розвитку 3С; зміни ïх складу та чисельності; економічні можливості держави щодо забезпечення визначених керівництвом завдань розвитку ЗС. Також для планування розвитку ЗС України необхідна інформація про перспективи розвитку ОВТ противника, зміни його воєнного та економічного потенціалу, про можливі райони виникнення конфліктів i ïx характер.

Для планування розвитку ЗС України необхідне проведення прогнозування перспектив. Об'єктами воєнного прогнозування має бути усе, що істотно впливає на завдання ЗС, їх склад, форми бойових дій та способи застосування сил i засобів, ефективність розвитку.

Прогноз - це результат оцінювання якісних і кількісних співвідношень показників на перспективу. Прогнозування показує, які зміни того чи іншого об'єкта відбудуться в тих чи інших умовах його розвитку. Прогнозування $\epsilon$ необхідним для планування, щоб можна було визначати орієнтири щодо можливостей розвитку сил та засобів, уявляти 
завдання та умови, в яких мають виконуватися ці завдання, та на цій основі готувати реальні (за воєнними, економічними та науково-технічними умовами) варіанти використання ресурсів, які потрібно виділяти на потреби оборони. Розвиток ЗС залежить від змін зовнішньої воєнно-політичної обстановки навколо країни, змін політики та економіки в середині країни, змін науково-технічного прогресу. Воєнне прогнозування можна поділити за трьома основними складовими: воєнно-стратегічне; воєнно-економічне та воєнно-технічне.

Воєнно-стратегічне

прогнозування охоплює характеристики можливих змін воєнно-політичної обстановки. Під час його проведення визначають можливі загрози безпеці України, склад ЗС противника або коаліції держав. Цей прогноз може мати характеристику політичних цілей противників й оцінку можливостей сторін щодо їх досягнення. Кінцевим результатом проведення воєнностратегічного прогнозу має бути формування обстановки під час різних можливих воєннополітичних ситуацій, 3 вибором найімовірніших та найнебажаніших. Таке прогнозування має показувати діапазон невизначеності щодо розвитку воєнно-політичної обстановки та дасть змогу уникнути значних помилок під час формулювання завдань 3С України на перспективу.

Воєнно-стратегічний прогноз $є$ фоном для оцінювання варіантів розвитку ЗС під час обгрунтування проектів програм розвитку 3С на середньо- та довгострокову перспективу. Він характеризує діапазон можливих змін воєнностратегічної обстановки, який має бути врахований під час планування розвитку ЗС. Результатом такого прогнозування $є$ те, що будуть визначені в більшості випадків в якісній формі завдання, які стоятимуть перед ЗС України та приблизні відповіді щодо шляхів їх рішення в тих чи інших умовах розвитку воєнно-політичної обстановки. За необхідності, у межах воєнностратегічного прогнозування може бути виділений спеціальний оперативно-тактичний прогноз, у якому можуть бути викладені можливі варіанти умов під час проведення операцій на різних напрямках воєнних дій та розглянуті можливі способи використання нових засобів збройної боротьби.

\section{Воснно-економічне прогнозування}

результат наукового передбачення тенденцій розвитку та можливостей економіки сторін щодо розроблення та виробництва ОВТ різних видів і забезпечення ведення війни різного характеру. Ця інформація може бути отримана на основі аналізу перспектив розвитку національної економіки держав супротивників, чисельності населення та інших елементів економічного потенціалу кожної з держав (табл. 2, 3, рис. 2).

Воснно-технічне прогнозування - $\epsilon$ результатом наукового передбачення шляхів розвитку комплексів ОВТ на довгострокову перспективу. Основним призначенням воєннотехнічного прогнозування $€$ інформування керівників і спеціалістів про нові можливості щодо створення ОВТ. Передбачити майбутнє 3 повною достовірністю не можливо, ступінь невизначеності $є$ в будь-якому прогнозі, та він суттєво залежить від особливостей об'єкта прогнозування. Наприклад, під час прогнозування розвитку 3С України на основі прогнозованого показника рівня забезпечення їх потреб, видно, що зі збільшенням горизонту прогнозування похибка збільшується та на довгострокову перспективу може складати 10$20 \%$.

Динаміка основних воснно-економічних факторів в період 2002 - 2018pp.

\begin{tabular}{|c|c|c|c|c|c|c|c|c|c|c|}
\hline 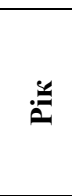 & 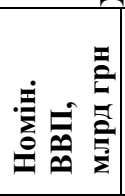 & 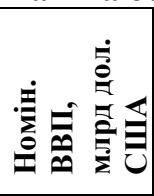 & 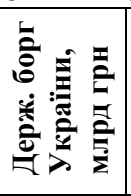 & 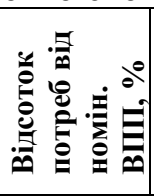 & 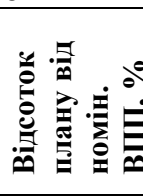 & 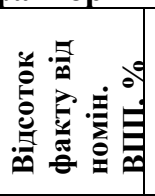 & 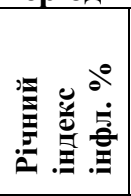 & 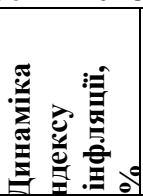 & 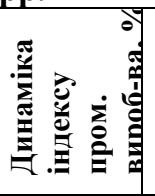 & 㻤 \\
\hline 2002 & 225,81 & 42,39 & & 3,47 & 1,64 & 1,36 & 125,8 & 5,60 & 98,10 & 15380 \\
\hline 2003 & 267,34 & 50,13 & & 3,35 & 1,66 & 1,56 & 106,10 & $-15,66$ & 101,80 & 15671 \\
\hline 2004 & 345,11 & 64,88 & 173,9 & 2,93 & 1,59 & 1,49 & 99,40 & $-6,31$ & 102,30 & 20329 \\
\hline 2005 & 441,45 & 86,14 & 175,7 & 3,17 & 1,34 & 1,32 & 108,20 & 8,85 & 107,90 & 15185 \\
\hline 2006 & 544,15 & 107,75 & 179,5 & 2,39 & 1,40 & 1,18 & 112,30 & 3,79 & 109,90 & 36910 \\
\hline 2007 & 720,73 & 142,72 & 197,0 & 1,82 & 1,27 & 1,12 & 110,30 & $-1,78$ & 111,50 & 3697 \\
\hline 2008 & 948,06 & 179,99 & 290,8 & 1,84 & 1,04 & 1,01 & 111,60 & 1,18 & 103,90 & -15493 \\
\hline 2009 & 913,35 & 117,23 & 316,9 & 3,50 & 1,40 & 0,91 & 116,60 & 4,48 & 109,50 & -41163 \\
\hline 2010 & 1082,57 & 136,42 & 432,2 & 1,86 & 1,15 & 0,97 & 122,30 & 4,89 & 97,60 & -75729 \\
\hline 2011 & 1316,60 & 163,16 & 473,1 & 1,03 & 1,05 & 0,97 & 112,30 & $-8,18$ & 95,30 & -15296 \\
\hline 2012 & 1408,89 & 175,78 & 515,5 & 1,55 & 1,16 & 1,05 & 109,10 & $-2,85$ & 103,50 & -31579 \\
\hline 2013 & 1454,93 & 183,31 & 584,1 & 1,68 & 1,07 & 1,04 & 104,60 & $-4,12$ & 103,20 & -71075 \\
\hline 2014 & 1566,73 & 131,81 & 1100,5 & 1,64 & 1,03 & 1,03 & 99,80 & $-4,59$ & 94,50 & -11805 \\
\hline 2015 & 1979,46 & 90,62 & 1572,2 & 4,04 & 2,12 & 1,93 & 100,50 & 0,70 & 98,90 & -12376 \\
\hline 2016 & 2383,18 & 93,27 & 1929,7 & 4,57 & 2,46 & 2,31 & 111,60 & 11,04 & 87,10 & -19111 \\
\hline 2017 & 2584,90 & 95,74 & 2146,7 & 4,17 & 2,49 & 2,22 & 109,60 & $-1,79$ & 93,40 & -17899 \\
\hline 2018 & 3332,30 & 111,08 & & 4,05 & 2,58 & 2,34 & & & & \\
\hline
\end{tabular}


Таблиця 3

Прогноз динаміки ВВП України та витрат на ЗС України в період 2018 - 2032 рр.

\begin{tabular}{|c|c|c|c|c|c|c|c|c|c|c|c|}
\hline$\ddot{\ddot{Z}}$ & 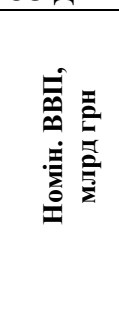 & 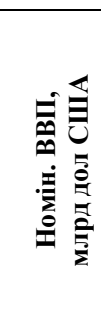 & 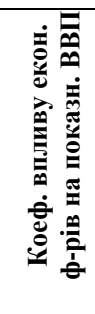 & 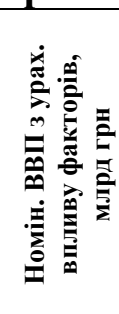 & 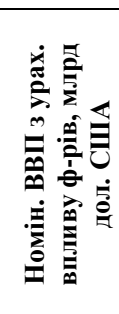 & 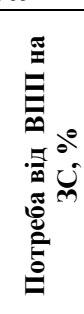 & 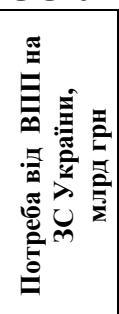 & 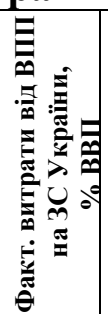 & 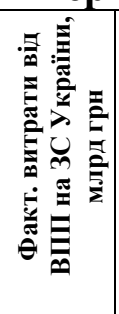 & 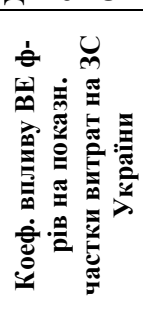 & 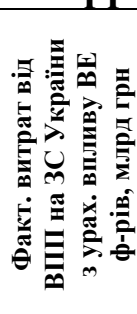 \\
\hline 2018 & 3332,3 & 111,08 & 1,08 & 3598,9 & 119,97 & 4,05 & 134,96 & 2,34 & 77,98 & 1,05 & 81,87 \\
\hline 2019 & 3931,5 & 125,74 & 1,03 & 4049,4 & 129,51 & 4,21 & 165,51 & 2,24 & 88,06 & 1,12 & 98,63 \\
\hline 2020 & 4621,5 & 133,32 & 0,87 & 4020,7 & 115,99 & 4,05 & 187,17 & 2,32 & 107,22 & 0,72 & 77,20 \\
\hline 2021 & 5413,4 & 124,48 & 0,73 & 3951,8 & 90,87 & 4,39 & 237,65 & 2,24 & 121,26 & 0,82 & 99,43 \\
\hline 2022 & 6318,9 & 138,22 & 1,08 & 6824,5 & 149,28 & 4,41 & 278,67 & 2,03 & 128,28 & 0,88 & 112,88 \\
\hline 2023 & 7350,9 & 140,95 & 1,19 & 8747,7 & 167,73 & 4,57 & 335,94 & 2,15 & 158,05 & 1,06 & 167,53 \\
\hline 2024 & 8523,1 & 125,98 & 1,04 & 8864,0 & 131,02 & 4,64 & 395,47 & 2,48 & 211,37 & 0,83 & 175,44 \\
\hline 2025 & 9849,9 & 165,96 & 0,96 & 9455,9 & 159,32 & 4,34 & 427,49 & 1,98 & 195,03 & 0,96 & 187,23 \\
\hline 2026 & 11347,2 & 171,85 & 0,79 & 8964,3 & 135,76 & 4,18 & 474,32 & 2,28 & 258,72 & 0,84 & 217,32 \\
\hline 2027 & 13031,5 & 167,19 & 0,81 & 10555,5 & 135,42 & 4,07 & 530,38 & 2,18 & 284,09 & 0,82 & 232,95 \\
\hline 2028 & 14920,2 & 99,92 & 1,08 & 16113,9 & 107,91 & 3,99 & 595,32 & 2,37 & 353,61 & 0,87 & 307,64 \\
\hline 2029 & 17031,9 & 164,09 & 1,02 & 17372,6 & 167,38 & 3,85 & 655,73 & 2,34 & 398,55 & 0,84 & 334,78 \\
\hline 2030 & 19386,0 & 133,67 & 0,89 & 17253,6 & 118,97 & 3,97 & 769,63 & 2,27 & 440,06 & 0,93 & 409,26 \\
\hline 2031 & 22002,7 & 190,94 & 0,92 & 20242,5 & 175,66 & 4,05 & 891,11 & 2,49 & 547,87 & 0,86 & 471,17 \\
\hline 2032 & 24903,1 & 197,19 & 0,94 & 23408,9 & 185,36 & 4,34 & 1080,8 & 2,45 & 610,12 & 0,81 & 494,20 \\
\hline
\end{tabular}

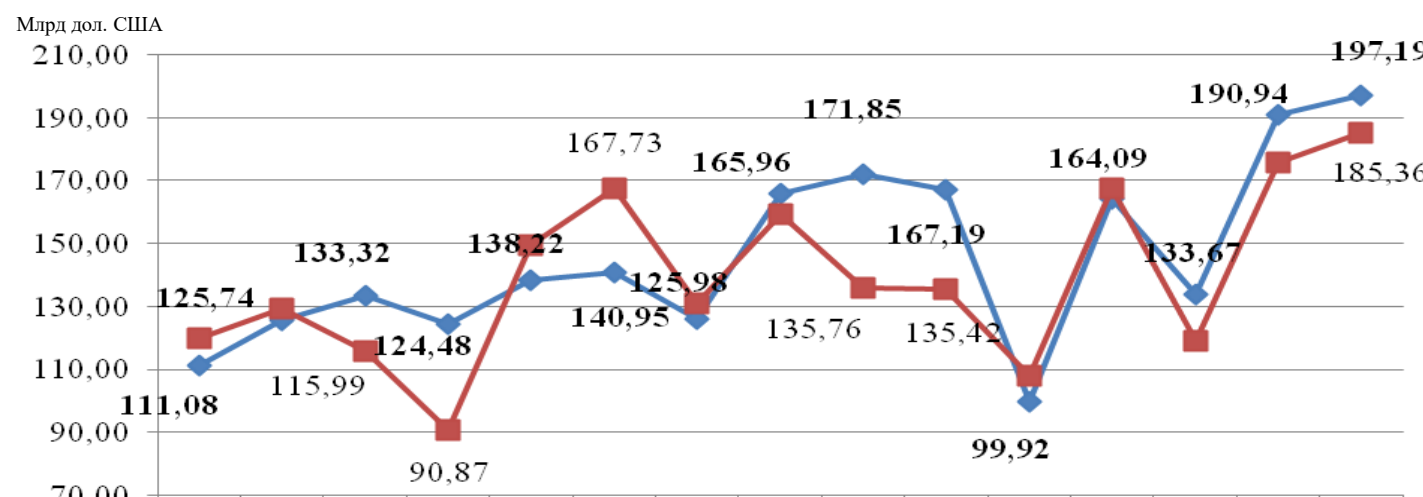

70,00

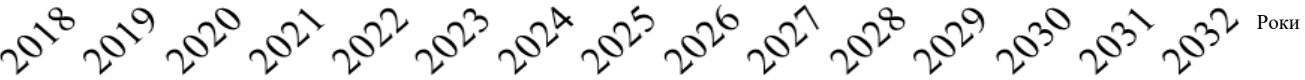

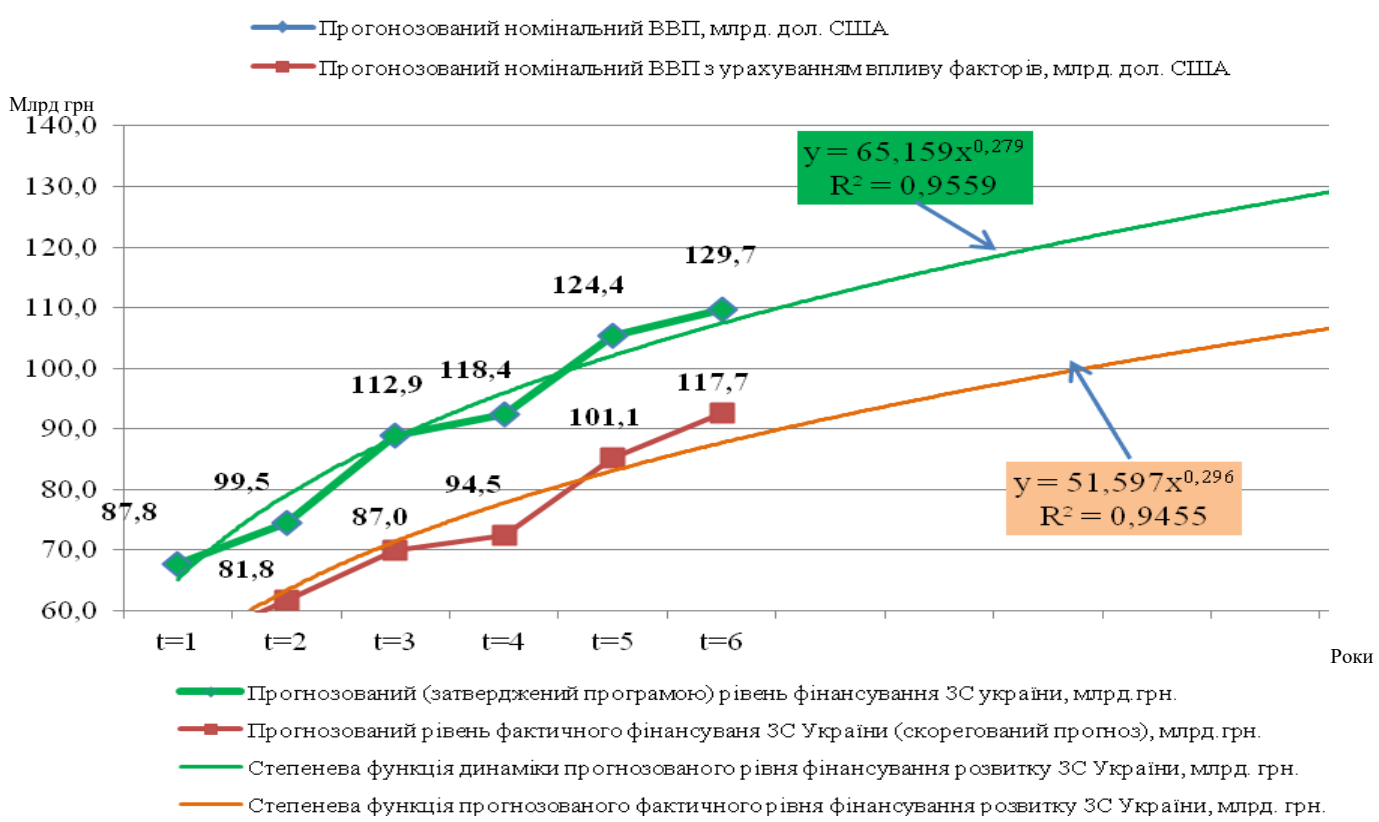

Рис. 2. Прогнозована динаміка ВВП України (1) та відповідна до цього прогнозована динаміка витрат на $3 С$ України на найближчі 6 років (2) 
Вивчення статистичної інформації щодо фінансування 3С України за показниками частки від ВВП і за показником загального обсягу фінансування ЗС України за роками досліджуваного періоду дає змогу сформувати загальні функціональні залежності щодо прогнозованої динаміки забезпечення 3С України фінансовими ресурсами на наступний довгостроковий період $2018-2032$ pp. як частку від прогнозованого показника ВВП (у доларовому та гривневому еквіваленті) (табл. 3, рис. 2). На рис. 2 відображено рекомендації щодо визначення прогнозованої динаміки рівня фінансування розвитку (спроможностей) ЗС України на довгострокову перспективу з порівнянням їх 3 визначеними попередньо показниками. Похибка складає від 9 до $21 \%$ за роками прогнозування.

Коливання прогнозу ВВП і витрат на 3С України обумовлені тим, що для прогнозування методом екстраполяції була обрана поліноміальна функція. Ця функція обрана за найкращим показником коефіцієнта детермінації обраної функції існуючим статистичним даним (табл. 1,2) за якими здійснювався прогноз, також їі обрано для прогнозування бо вона давала змогу якісніше врахувати фактор інфляції, тобто періодичність його впливу як на показники ВВП країни, так і на показники витрат на ЗС України як частку від ВВП.

Проведений аналіз стану забезпечення 3С України фінансовими ресурсами та результати прогнозування на їх основі дають змогу сформувати багатоваріантну картину майбутнього. Під час прогнозування дуже важливо виявити найімовірніші характеристики умов розвитку 3С, але розв'язання такої задачі $є$ дуже складним, оскільки передбачення обстановки, яка може скластися в майбутньому, завжди обумовлено об'єктивними умовами реальної дійсності. Отже, наскільки повним буде уявлення про можливі варіанти обстановки, яка може скластися в майбутньому, залежить об’єктивність оцінки та правильність обраних напрямів розвитку 3 С України.

Воєнно-економічне

обгрунтування завдань ЗС України є однією з найважливіших умов підвищення ефективності використання ресурсів, які виділяються на оборонні потреби. Зміст стратегічних завдань стає параметром, за яким проводиться оптимізація планів і програм розвитку ЗС України. Під час обгрунтування стратегічних завдань розглядаються різні варіанти воєнно- політичної обстановки, які визначені на основі комплексного прогнозування. Для кожного 3 основних варіантів воєнно-політичної обстановки відповідно до визначених політичних цілей $\mathrm{i}$ визначеного ймовірного противника формулюються можливі стратегічні завдання на головних і другорядних напрямках можливих воєнних дій. Одночасно потрібно визначати потреби в силах і засобах для виконання завдань та здійснюватися пошук шляхів їх можливого поєднання відповідно до виділених державою ресурсів. Вибір найкращого поєднання стратегічних завдань ЗС України має бути основою для планування розвитку 3С. Головною рисою визначеного варіанта поєднання стратегічних завдань ЗС $є$ реальність їх виконання з урахуванням рівня забезпеченості необхідними ресурсами. Потреби в силах і засобах для виконання завдань 3С визначаються спеціальними методами та математичними моделями ведення бойових дій. Співставлення визначеного складу сил і засобів (3 урахуванням їх динаміки) 3 потребами дасть змогу визначити необхідну кількість ОВТ, яку потрібно отримати 3 національної економіки та сформулювати задачі подальших досліджень та розробок щодо оновлення або удосконалення OBT. Однією 3 характерних тенденцій розвитку ЗС є поява нових видів і родів військ, або зміна функцій нинішніх.

Головною рисою ефективного використання оборонних ресурсів $\epsilon$ підпорядкованість планування розвитку ЗС України та їх структурних елементів, завданням, які постають перед ЗС загалом. Отже необхідно постійно застосовувати комплексний та системний підхід до планування будівництва ЗС України 3 подальшою інтеграцією планування розвитку усіх структурних елементів в єдину систему планування розвитку ЗС України.

Найадекватнішим методом комплексного вирішення питань щодо розвитку сил і засобів, які мають однакове цільове призначення, але належать до різних видів ЗС $€$ метод програмно-цільового планування. Сучасні методи планування розвитку ЗС України на основі спроможностей є його інтерпретацією 3 акцентом на систему планування розвитку ЗС країн НАТО. Проте ці методи як і метод програмно-цільового планування передбачають застосування однакових інструментів планування - цільові комплексні програми, які орієнтовані на створення сил і засобів для виконання стратегічних завдань ЗС України. Основним призначенням цільових 
комплексних програм $€$ забезпечення максимально можливої узгодженості завдань, які покладені на 3С України та їх структурні елементи, із завданнями, які стоять перед 3С загалом.

Розроблення цільових комплексних програм розвитку 3С України в сучасних умовах їх розвитку, під час переходу функціонування системи оборонного планування використанням методу планування на основі спроможностей, $\epsilon$ об'єктивною необхідністю сьогодення. Але розроблення загальних, стандартизованих підходів до їх формування є нині складною проблемою стратегічного значення. Для iï реалізації необхідні глибокі теоретичні та практичні дослідження за досвідом планування розвитку інших країн світу. Дослідження цієї проблеми передбачає розроблення нових методологічних основ воєнно-економічного обгрунтування цілей i змісту цих програм, а також методологічних основ прогнозування та моделювання розвитку 3С України на довгострокову перспективу. Цільовій комплексній програмі розвитку 3С України потрібно мати директивний характер за основною ціллю, але залежно від впливів факторів щодо зміни обстановки навколо їй потрібно мати можливість адаптуватися (коригуватися) під обставини (обмеження) за роками ¥і1 виконання. Щороку вона має коригуватися, продовжуватися або навпаки самостійно закінчитися у разі їі недоцільності.

Головна перевага цільових програм в тому, що вони дають змогу привести систему планування розвитку 3С України у повну відповідність до нових умов їх функціонування без радикальної зміни їх організаційної структури. Цільові комплексні програми мають бути концепцією детальніших планів розвитку видів 3С та їх структурних елементів. Для розроблення цільових комплексних програм розвитку 3С України необхідно вирішити питання щодо їх класифікації. Програми, наприклад, можуть бути побудовані за принципом відповідності ïx стратегічним завданням 3С України, за географічним або територіальним принципом тощо. Якщо за територіальним принципом, тоді в одну цільову програму поєднуються заходи щодо створення сил і засобів, які призначені для використання на визначеному театрі дій. Одним 3 основних принципів комплексного планування розвитку 3С України є його безперервність, тому завчасно необхідно визначити найдоцільніші послідовності та строки їх розроблення, оцінювання, коригування та продовження тривалості, створити дорожню карту.

Висновок та напрям подальших досліджень. Проведений у статті аналіз стану фінансового забезпечення 3С України фінансовими ресурсам i здійснений прогноз цього стану на довгострокову перспективу методом екстраполяції, а також дослідження питань комплексного планування розвитку 3С України дає змогу сформувати основні етапи його реалізації в системі оборонного планування:

перший - розроблення воєнностратегічного, воєнно-економічного, воєннотехнічного прогнозів, підготовки завдань на розроблення $\mathrm{i}$ розроблення прогнозів за окремими напрямами розвитку 3С України;

другий - обгрунтування політичних цілей, на які буде орієнтовано воєнне будівництво, обсягів необхідних ресурсів для досягнення визначених цілей. Цей етап складається $з$ процедур: визначення можливих політичних цілей i сукупності завдань, виконання яких забезпечує досягнення визначеної цілі (для кожної цілі за основними напрямом воєнного будівництва); розрахунок потреб у ресурсах для виконання завдань, які забезпечують досягання кожної цілі, отримання залежності "ціль-витрати"; формування можливих поєднань цілей i визначення сумарних потреб у ресурсах для їх досягнення; вибір раціонального поєднання, цілей які можуть бути досягнуті за визначеного обсягу ресурсів, які виділяються на будівництво ЗС України; затвердження завдань, які забезпечують досягнення обраних цілей за основним напрямом воєнного будівництва, зокрема стратегічних задач 3С України;

третій -розроблення плану розвитку 3С України: визначення динаміки змін бойового складу 3С за роками, орієнтовних потреб у силах i засобах для виконання затверджених стратегічних завдань та додаткових потреб у силах і засобах, підготовка плану;

четвертий - розроблення цільових комплексних програм розвитку 3С, основних напрямів розвитку ОВТ та програм озброєння: обгрунтування необхідного (доцільного) складу сил і засобів для виконання завдань 3С України (визначення раціональних пропорцій сил і засобів різних видів 3С, обгрунтування змісту завдань для планування розвитку сил i засобів ЗС та встановлення обсягів необхідних для цього ресурсів); 
п’ятий - розроблення планів розвитку видів 3С, за кожним видом окремо: аналіз та уточнення завдань, які стоять перед видом 3С, та обсягів ресурсів, які йому виділяються (за сукупністю усіх програм); уточнення додаткових потреб у силах і засобах виду ЗС для виконання завдань, які сформульовані у різних програмах, уточнення потреб у pecypcax, визначення можливостей промисловості, підготовка проекту плану розвитку.

Планування i розроблення цільових програм i планів доцільно здійснювати методом послідовних наближень, тобто спочатку необхідно розробляти різні варіанти проектів програм (планів), а потім уточнювати їх за допомогою відповідних балансових та інших моделей і методів.

\section{СПИСОК ВИКОРИСТАНОЇ ЛІТЕРАТУРИ}

1. Елементи дослідження складних систем військового призначення / О.М.Загорка, С. П. Мосов, А. І. Сбитнев, П. І. Стужук. Київ: HAOУ, 2005. $100 \mathrm{c}$.

2. Пріоритети розвитку Збройних Сил України 3 урахуванням участі у гібридній війні 20152016 / [Електронний ресурс]. - Режим доступу: http//www.president.gov.ua/documents.

3. Україна 2014-2015: Долаючи виклики (аналітичні оцінки) / [Електронний ресурс]. - Режим доступу: http//www.razumkov.org.ua/upload/Pidsumky_2015_ 2016_A4_fnl.pdf.

4. Сучасний стан Збройних Сил України [Електронний pесурс]. - Режим доступу: defpol.org.ua/site/index.php/ru/.../stan2016.

Стаття надійшла до редакції 12.03.2019

Бойко Р. В. к.т.н., с.н.с. ${ }^{1}$;

Семененко О. М. д.воен.н., с.н.с. ${ }^{2}$;

Водчиць О. Г .; к.т.Н., доцент ${ }^{3}$;

Добровольський Ю. Б. к.Т.Н., доцент ${ }^{3}$;

Абрамов А. П. ${ }^{2}$

1 - Центр военно-стратегических исследований Национального университета обороны Украины имени Ивана Черняховского, Киев;

2 - Центральный научно-исследовательский институт Вооружённых Сил Украины, Киев;

3 - Военная кафедра Национального авиационного университета, Киев

Анализ состояния обеспечения Вооруженных Сил Украины финансовыми ресурсами и порядок комплексного планирования их развития

Резюме. В статье проведен анализ состояния финансового обеспечения Вооружённых Сил Украины финансовыми ресурсами в 2005 - 2018 годах и сделан прогноз этого состояния на долгосрочную перспективу методом экстраполяции, а также определен порядок комплексного планирования развития Вооружённых Сил Украины по основным этапам его реализации в системе оборонного планирования.

Ключевые слова: экономическое обеспечение; комплексное планирование развития Вооруженных Сил Украины; стратегическое планирование; ресурсное обеспечение; потребности вооруженных сил; военно-экономические требования.

R. Boiko, PhD (Technical), senior researcher ${ }^{1}$;

O. Semenenko, DsM, assistant professor ${ }^{2}$;

O. Vodchyts, PhD (Technical), senior researcher ${ }^{3}$;

Y. Dobrovolsky, PhD (Technical), senior researcher ${ }^{3}$;

A. Abramov ${ }^{2}$

1 - Center for Military and Strategic Studies of the National Defence University of Ukraine named after Ivan Cherniakhovskyi, Kyiv;

2 - Central Research Institute of the Armed Forces of Ukraine, Kiev;

3 - Military Department of the National Aviation University, Kiev

Analysis of the provision of the Armed Forces with financial resources and the order of integrate planning of their development

Resume. The article analyzes the state of providing of the Armed Forces of Ukraine with financial resources and makes a forecast of this state on the pre-therm pseudobuld by the method of the order of complex planning of their development

Keywords: economic provision; comprehensive planning of the development of the Armed Forces of Ukraine; strategic planning; resource support; needs of the Armed Forces; military-economic requirements. 